Hal. $143-152$

\title{
EFEKTIFITAS AIR REBUSAN DAUN BINAHONG DENGAN KESEMBUHAN LUKA PERINEUM PADA IBU NIFAS TAHUN 2019
}

\author{
The effectiveness Of Maderavine Leaves Decoction With Perineal Wounds Healing In Postpartum \\ Mothers In 2019
}

\author{
Elvi Era Liesmayani ${ }^{*}$, Sulastri ${ }^{2}$, Novalita Oriza ${ }^{3}$ \\ ${ }^{1}$ Dosen D4 Kebidanan, Fakultas Farmasi Dan Kesehatan, Institut Kesehatan Helvetia, Medan, Indonesia \\ ${ }^{2}$ Mahasiswa D4 Kebidanan, Fakultas Farmasi Dan Kesehatan, Institut Kesehatan Helvetia, Medan, Indonesia \\ ${ }^{3}$ Dosen D4 Kebidanan, Fakultas Farmasi Dan Kesehatan, Institut Kesehatan Helvetia, Medan, Indonesia \\ Email: viedilovevy @gmail.com \\ *Penulis Korespondensi
}

\begin{abstract}
Abstrak
Pendahuluan: Robekan perineum adalah robekan yang terjadi pada perineum waktu persalinan dan terjadi pada hampir semua persalinan pertama dan juga tidak jarang pada persalinan berikutnya. Tanaman binahong dipercaya bisa mempercepat pemulihan kesembuhan diantaranya luka robekan perineum. Tujuan: tujuan dilakukannya penelitian ini adalah untuk mengetahui kecukupan air rebusan daun binahong dengan penyembuhan luka perineum pada ibu pasca hamil di Sri Diana Lubis Center tahun 2019. Motivasi di balik pemeriksaan ini adalah untuk membedah viabilitas air rebusan daun binahong dengan perbaikan luka perineum. wanita pasca hamil di Fasilitas Sri Diana Lubis pada tahun 2019. Metode: Desain penelitian menggunakan quasi experimen dengan pendekatan static group comparison yaitu peneelitian yang perlakuan telah dilakukan, kemudian dilakukan observasi atau postes. Populasi dalam penelitian ini adalah seluruh ibu nifas 2 hari postpartum yang mengalami robekan derajat II sebanyak 10 orang dan seluruhnya dijadikan sampel (total populasi). Analisis data menggunakan data univariat dan bivariat dengan menggunakan uji Sign-Wilcoxon test. Hasil: Hasil penelitian menunjukan bahwa efektifitas kesumbuhan Luka Perineum Pada Ibu Nifas yang mengkonsumi air rebusan daun binahong dengan keseumbuhan luka cepat $<6$ hari sebanyak 5 orang $(50 \%)$, sedangkan yang tidak mengkonsumsi dengan kesembuhan luka normal 6-7 hari sebanyak 3 orang (30\%) dan kesembuhan luka lambat sebanyak 2 orang (20\%). Kesimpulan: Kesimpulan ada pengaruh efektifitas air rebusan daun binahong dengan kesembuhan luka perineum pada ibu nifas di Klinik Sri Diana Lubis Tahun 2019. Disarankan bagi petugas kesehatan agar mendukung ibu nifas untuk menggunakan air rebusan daun binahong bisa mempercepat kesembuhan luka perineum pada ibu nifas.
\end{abstract}

\begin{abstract}
Background: Perineal tears occur in the perineum during labor and in almost all first deliveries and also not infrequently in subsequent deliveries. Maderavine plants are believed to accelerate recovery, including perineal lacerations. Objectives: This study aimed to analyze the effectiveness of Maderavine leaves decoction with perineal wounds healing in postpartum mothers at Sri Diana Lubis Clinic in 2019. Method; The study design used a quasi-experimental approach with a static group comparison approach, namely research that had been done and then conducted observations or posttests. The populations in this study were all 2 days postpartum mothers who experienced second degree tears of 10 people and all of them were sampled (total population). Data analysis used univariate and bivariate data by the Sign-Wilcoxon test. Results: The results showed that the effectiveness of perineum wounds healing in postpartum mothers who consumed Maderavine leaves decoction with fast wound healing $<6$ days by 5 people (50\%), while those who did not consume with normal wound healing for 6-7 days were 3 people (30\%) and slow wound healing by 2 people (20\%). Conclusion: The conclusion shows that there is an effect of Maderavine leaves decoction with perineal wounds healing in postpartum mothers at Sri Diana Lubis Clinic in 2019. It is suggested for health workers to support postpartum mothers to use Maderavine leaves decoction to accelerate the healing of perineal wounds.
\end{abstract}

Keywords: Maderavine Leaves, Perineum Wound 
Hal. $143-152$

\section{PEDAHULUAN}

Tumbuhan terapeutik adalah tumbuhan yang memiliki khasiat memulihkan d an dimanfaatkan sebagai obat dalam penyembuhan dan pencegahan penyakit. Tumbuhan terapeutik mengan dung zat dinamis yang mampu mengobati penyakit tertentu dari zat lain yang mampu mengobati. Dalam pemanfaatan tumbuhan terapeutik sebagai obat dapat diplester, ditempel, dicuci, dihirup dengan tujuan agar pemanfaatannya dapat memenuhi gagasan kerja sel dalam mendapatkan campuran zat atau penguat.

Salah satu tanaman terapeutik yang berharga adalah tanaman Binahong, tanaman Binahong merupakan salah satu obat tradisional yang dimanfaatkan oleh masyarakat setempat sebagai pengobatan pilihan, tanaman binahong memiliki kandungan zat yang sangat bermanfaat sebagai bahan pengikat pengobatan yang khas. Manfaat tanaman binahong dapat mempercepat pemulihan kesehatan setelah prosedur medis, setelah persalinan, sunat, berbagai luka dalam, luka luar, iritasi usus, s tan dar kematian, ketegangan peredaran darah, mencegah stroke, bisul, asam urat, meningkatkan dan memulihkan kekebalan tubuh. Wasir (hemps) ), pipis halus dan kentut dan kencing manis. Kandungan zat pada tanaman Binahong terdapat Ascorbar Corrosive (nutrisi C) yang dapat membangun perlindungan tubuh dari kontaminasi, kemampuan dalam memelihara selaput len dir, mem percep at perbaikan dan sebagai penguat sel, korosif askorbat sangat penting untuk mengaktif kan senyawa prolyl. hydrox ylale yang menjunjung tinggi susunan kolagen. Dengan korosif askorbat ini, k olagen yang terbentuk akan lebih membumi dan mempercepat pemulihan cedera.Pada ibu pascahamil y ang mengalami luka gores atau luka perineum sebes ar $70 \%$, agar luka perineum sembuh dengan cepat agar penyakit tidak terjadi, maka, kemudian gunakan air rebusan dari daun binahong, luka perine u m ak an segera kering sebaliknya tidak memanfaatkan air rebusan daun binahong.

Masa nifas dimulai setelah plasenta lahir dan saat uterus kembali ke keadaan sebelum hamil, yang berlangsung sekitar satu setengah bulan atau \pm 40 hari. Masa awal tertentu setelah melahirk an an ak, dalam bahasa latin disebut masa nifas. Jadi masanifas adalah masa sesud ah melah irk an an ak dan disebut masa penyembuhan, dengan tujuan untuk memulihkan kembali alat-alat pembu ahan s ep erti sebelum hamil. Dikutip dari Dinas Kekuatan Republik Indonesia, perawatan pascakehamilan adalah cara untuk menentukan pilihan dan kegiatan yang diambil oleh spesialis persalinan s ela ma periode pasca kehamilan sesuai dengan posisi dan tingkat pelatihan tergantung pada informasi dan tips perawatan bersalin (1).

Robekan perineum adalah robekan yang terjadi pada perineum selama bekerja dan terjadi p ada hampir semua alat angkut pertama dan bukan hasil angkut yang tidak konsisten. Perineum adalah pemuasan kebutuhan untuk menopang daerah antara paha yang terbatas pada vulv a dan pantat ibu selama pengeluaran plasenta sampai datangnya organ-organ herediter seperti pada masa sebelum kehamilan. Sebagian besar robekan perineum terjadi selama persalinan dan pemberiannya melibatkan kebidanan. Robekan perineum dapat terjadi secara tiba-tiba atau karena episiotomi (2).

Ketika kepala anak menonjol di depan vagina, perineum biasanya akan meregang untuk membuka jalan bagi anak untuk melarikan diri. Sebagian dari kebutuhan ini menjelaskan bahwa perineum adalah ruang kulit dan otot dengan panjang normal sekitar $4 \mathrm{~cm}$, terletak di an tar a bagian belakang dan vagina y ang dapat robek selama persalin an atau sengaja diiris untuk bekerja dengan al at angkut. dari anak (3).

Daun binahong mengandung saponin, alkaloid dan polifenol. Saponin adalah campuran d in amis permukaan dan seperti pembersih. Ekstraksi senyawa sapoin akan memberikan hasil yang leb ih ba ik sebagai musuh bakteri bila menggunakan pelarut polar, mis alnya zat $70 \%$ pada daun binahong. Dilihat dari konstruksinya, ada dua macam saponin, yaitu steroid spesifik dan triterpenoid. Sap onin s tero id ditemukan di monokotil dan saponin triterpenoid ditemukan di dikotil. Saponin merangsang perkembangan kolagen, yang merupakan protein utama yang berperan dalam pro se s pen yem bu han luka (4).

Berdasarkan informasi dari World Health Organization (WHO) pada tahun 2017, s ekitar 830 wanita meninggal setiap hari karena komplikasi selama kehamilan atau persalinan. Untuk mengurangi 


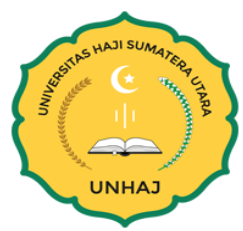

bahaya kematian ibu secara universal dari 216,1 juta kelahiran hidup pada tah un 2015 menjadi 70 untuk setiap 100.000 kelahiran hidup pada tahun 2030. Target SDGs akan membutuhkan laju penurunan tahunan di seluruh dunia pada dasarnya $7,5 \%$ yang merupakan beberapa kali laju penurunan tahunan yang diharapkan tercapai di suatu tempat di kisaran tahun 1990 dan 2015. Sebagian besar kematian ibu dapat dicegah karena mediasi klinis yang diperlukan dik etahui. Oleh karena itu, tingkatkan perhatian wanita terhadap pertimbangan kualitas sebelum, selama, dan s etelah persalinan (5).

Berdasarkan informasi dari Dinas Kesehatan tahun 2016, penyebab kematian ibu di Ind on esia masih diliputi oleh tiga faktor utama penyebab kematian, yaitu kematian, hipertensi dalam kehamilan (HDK), dan penyakit. Meskipun demikian, tingkatnya telah berubah, di mana pengeringan dan kontaminasi pada umumnya akan berkurang sementara tingkat HDK meningkat. Lebih dari $25 \%$ kematian ibu di Indonesia padatahun 2013 disebabkan oleh HDK (6).

Seperti yang ditunjukkan oleh Profil Kesejahteraan RI 2017, secara keseluruhan terjadi penurunan kematian ibu selama periode 1991-2015. Terjadi penurunan AKI di Indonesia. Upaya untuk mempercepat penurunan AKI harus dapat dilakukan dengan memastikan bahwa setiap ibu dapat memperoleh pelayanan kesehatan ibu yang berkualitas, seperti pelayanan kesehatan ibu hamil, bantuan persalinan melalui tenaga kesehatan terlatih di kantor pelayanan kesehatan, pelayanan kesehatan pasca melahirkan bagi ibu. dan anak-anak, pertimbangan dan referensi yang luar biasajik a terjad i kris is. kompleksitas, penerimaan sederhana untuk cuti hamil dan melahirkan, dan ad ministrasi men gatur keluarga. Selama tahun 2006 hingga 2017 masuknya pelayanan kesehatan ibu hamil K4 secara um um akan meningkat. Jika dibandingkan dengan tujuan Renstra Pelayanan Kesejahteraan Tahun 2017 yang sebesar 76\%, maka pencapaian tahun 2017 telah mencapai target tahun (7).

Seperti yang ditunjukkan oleh Profil Kesejahteraan Sumut 2016, jumlah kematian ibu di Me dan (2016) adalah 3 orang dari 47.541 kelahiran hidup, dengan Angka Kematian Ib u (AKI) terungkap sebes ar 6 untuk setiap 100.000 kelahiran hidup, menyiratkan bahwa dari 100.000 kelah iran hidup 6 ibu menendang ember selama kehamilan., persalinan, atau masa nifas. AKI di Kota Medan mengalami penurunan jika dibandingkan dengan tahun sebelumnya. Dimana pada tahun 2015 ju mlah persalinan bersalin sebanyak 6 orang dari 49.251 kelahiran hidup, pada tahun 2014 jumla h persalin an bersalin sebanyak 7 orang dari 48.352 kelahiran hidup dengan AKI 14 per 100.000 kelahiran hid up dan pada tahun 2013 jumlah persalinan bersalin sebanyak 9 orang. individu dengan AKI 21 untuk setiap 100.000 kelahiran. hidup(8).

Seperti yang ditunjukkan oleh Profil Kesejahteraan Kota Binjai tahun 2017, jumlah kematian ib u pada tahun 2012 tercatat sebesar 38,2 per 100.000 kelahiran hidup, sedangkan pada tahun 2013 sebesar 95 per 100.000 kelahiran hidup. Pada tahun 2014 angka kematian ibu yang terun gkap ad alah 73 untuk setiap 100.000 kelahiran hidup dan pada tahun 2015 menjadi 76 untuk setiap 100.000 kelahiran hidup, sedangkan pada tahun 2016 angka kematian ibu diperluas dari informasi yang dirin ci sebesar 131 untuk setiap 100.000 kelahiran hidup. Untuk tahun2017, rincian angk a kematian ibu adalah 131 untuk setiap 100.000 kelahiran hidup(9).

Seperti yang ditunjukkan oleh Profil Kesejahteraan Wilayah Asahan 2017, jumlah kelahiran hidup $(\mathrm{KH})$ tidak mencapai $100.000 \mathrm{KH}$, sehingga penyajian angka kematian ibu cukup untuk mencatat pembilang dan penyebut tanpa menduplikasinya dengan konsisten $100.000 \mathrm{KH}$. Pada tah u n 2014 terdapat 13.564 kelahiran hidup dengan 16 kematian ibu; terdiri dari $3(18,75 \%)$ ke matian ibu terjadi selama kehamilan, $10(62,50 \%)$ kematian ibu terjadi selama persalinan, dan $3(18,75 \%)$ kematian ibu terjadi pada masa nifas. Kepergian ini terjadi pada kelompok usia 20-34 tahun ke atas sebanyak $10 \mathrm{ibu}(62,5 \%)$, dan kelompok usia 35 tahun ke atas sebanyak $6 \mathrm{ibu}(37,50 \%)$. Pad a tah un 2015 jumlah kelahiran hidup adalah 14.125 dengan jumlah persalinan meningkat menjadi 24; Terd iri dari $9(37,50 \%)$ maternal passing terjadi selamakehamilan dengan usia ibu 20-34 tahun, $9(37,50 \%)$ maternal terjadi pada saat persalinan, dan $6(25,00 \%)$ maternal terjadi pad a masa nifas. Kepergian ini (100.00\%) terjadi pada pertemuan ibu-ibu yang berusia 20-34 tahun. Pada tahun 2016 jumlah kelahiran hidup adalah 13.645 dengan jumlah persalinan turun menjadi 13 ; terdiri dari $2(15,38 \%)$ 


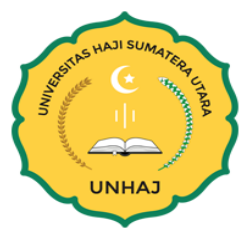

kematian ibu terjadi selama kehamilan dengan usia ibu 20-34 tahun, $7(53,85 \%)$ kematian ibu ter jad i pada usia 20-34 tahun, dan $4(30,77 \%))$ kematian ibu terjadi pada jam pasca kehamilan us ia 20-34 tahun ( 3 individu) dan usia 35 tahun ( 1 individu). Untuk sementara, pada tahun 2017 jumlah kelahiran hidup sebanyak 13.847 dengan jumlah persalinan turun menjadi 11; terdiri dari $1(18,10 \%)$ kem atian ibu terjadi selama kehamilan dengan usia ibu 20-34 tahun, 2 pada saat $>35$ tahun $(18,10 \%) .3(27.00 \%)$ kematian ibu terjadi ketika ibu mengandung anak pada usia usia 20-34 tahun, dan $4(36,00 \%)$ kematian ibu terjadi pada mas a nifas matur 20-34 tahun (3 individu) dan usia 35 tahun (1 orang) (9).

Seperti yang diungkapkan oleh Dewi Maritalia pada tahun 2017, perawatan pada masa pasca kehamilan perlu diperhatikan karena sekitar $60 \%$ dari angka kematian ibu terjadi selama periode ini. Angka Kematian Ibu (AKI) adalah jumlah wanita yang menggigit debu dari satu penyebab kematian diidentifikasi dengan masalah kehamilan dan administrasi mereka (kecuali kecelakaan atau kasus kebetulan) selama kehamilan, persalinan dan nifas (42 hari setelah hamil keturunan) tanpa mempertimbangkan lama kebuntingan per 100.000 kelahiran hidup. (10).

Menurut Wijayanti 2016 dalam buku harian Raden Roro Siti Hatati Surjantini dan Yusniar Siregar Di Indonesia, luka memar atau perineum dapat dialami oleh $75 \%$ wanita yang hamil melalu i vagina. Pada tahun 2013 melacak bahwa dari jumlah 1951 persalinan pervaginam tanpa kendala, 57\% ibu mendapat jahitan perineum (28\% karena episiotomi dan 29\% karena robek an tanpa batas) (11).

Tujuan pemeriksaan ini adalah untuk memutuskan kecukupan air rebusan daun binahong den gan perbaikan cedera perineum pada ibu pasca hamil di Fasilitas Sri Diana Lubis tahun 2019

\section{METODE PENELITIAN}

Desain penelitian ini adalah quasi experimen dengan pendekatan Static Group Comparison yaitu penelitian yang perlakuan telah dilakukan, kemudian dilakukan observasi atau postes. Desain penelitian ini mempunyai kelompok eksperimen dan kelompok kontrol. Kelompok yang mendapatkan perlaku an yang diikuti dengan pengukuran kedua (postes), kemudian hasil pengukuran in i ak an dib andingk an dengan hasil pengukuran pada kelompok pembanding (kontrol) yang tidak menerima perlakuan (12).

Lokasi penelitian adalah tempat dimana penelitian dilaksanakan. Lokasi pada penelitian ini dilakukan di Klinik Sri Diana Lubis Tahun 2019. Waktu penelitian ini dilaksanakan dari mulai s urvei awal pada bulan Meisampai selesai penelitian bulan Juli 2019.

Populasi adalah keseluruhan objek penelitian ini adalah seluruh ibu nifas 2 hari postpartum yang mengalami robekan derajat II sebanyak 10 orang pada bulan Julidi Klinik Sri Diana Lubis Tahun 2019(13). Sampel dalam penelitian ini menggunakan Accidental Sampling yaitu s elu ru h ibu yang bersalin di bulan Juli tahun 2019 sebanyak 10 orang.

Metode data dalam penelaitian ini menggunakan Data primer yaitu data yang diperoleh langsung melalui wawancara kepada responden dan observasi dengan menggunakan kuesioner yang telah berisi daftar pertanyaan serta jawaban yang telah dipersiapkan. Data sekunder adalah data yang diperoleh d ari hasil dokumantasi oleh pihak lain, misalnya rekam medik, rekapitulasinilai, datakonjungan pasien, d an lain-lain. Data tersier adalah data yang diperoleh dari naskah yang sudah dip ub likasikan, misaln ya seperti WHO, SDKI (Survei Demografi Kesehatan Indonesi). Riskesdes Tahun(Riset Kesehatan Dasar)

Analisis yang digunakan yaitu Analisis Univariat digunakan untuk mendeskripsikan d ata y ang dilakukan pada tiap variabel dari hasil penelitian. Data disajikan dalam tabel distribusi frekuensi. Setelah diketahui karakteristik masing-masing variabel pada penelitian ini maka analisis dilanjutkan pada tingkat bivariat. Untuk mengetahui hubungan (korelasi) antara variabel bebas (Independent Variabel) d engan variabel terikat (Dependen Variabel). 
Hal. $143-152$

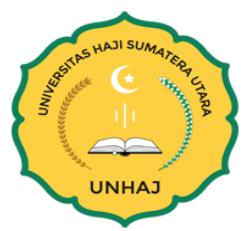

\section{HASIL}

\section{Analisis Uji Wilcoxon Signed Ranks Test}

Berdasarkan tabel 1 Efektifitas Frekuensi Responden pada Kelompok Eksperimen Berdas arkan Lama Kesembuhan Luka Pada Ibu Nifas Di Klinik Sri DianaLubis Mutiara Kecamatan Kisaran bahwa seluruh ibu nifas di Klinik Sri DianaLubis MutiaraKisaran yang diberikan air rebusan daun binah on ng seluruh ibu nifas yang mengalami kesembuhan luka cepat yaitu $100 \%$, penelitian in i terlihat bahwa ekstrak daun binahong mampu mempercepat pengecilan ukuran lukaperineum. Hal in i m enun juk kan terjadiny a proses penyembuhan luka perineum pada ibu nifas, kemampuan ini tidak terlepas dari adanya kandungan senyawa aktif yang terdapat pada daun binahong. Dis tribusi Rata-Rata Kes em bu han Lu ka Perineum Pada Ibu Nifas Kelompok Ekperimen Menurut Penggukuran Per-Tes Dan Post-Test. Kesembuhan luka pada pengukuran Pre-Tes adalah 15.00 standar 0.000 sedangkan pengukuran Kesembuhan luka Post-Test adalah 3.80 standar 2.168, terlihat dari P-value 0.042 maka dapat disimpulkan ada perbedaan yang signifikan antara kesembuhan luka pre-test dan kesembuhan luka posttest pada kelompok eksperimen, pada penelitian ini terlihat bahwa eks trak daun binahong mam pu mempercepat pengecilan ukuran luka perineum. Hal ini menunjukkan terjadinya proses p en ye mbuh an luka perineum pada ibu nifas, kemampuan ini tidak terlepas dari adanya kandungan senyawa aktif y ang terdapat pada daun binahong.

Tabel 1. Efektifitas Frekuensi Responden pada Kelompok Eksperimen Berdasarkan Lama Kesembuhan Luka Pada Ibu Nifas Di Klinik Sri Diana Lubis Mutiara Kecamatan Kisaran Tahun 2019

\begin{tabular}{cccccc}
\hline Kesembuhan & f & \multicolumn{3}{c}{$\%$} \\
\hline Cepat & 5 & & 100 & \\
Normal & - & & - & \\
Lama & - & & - & \\
\hline Variabel & Mean & SD & P-value & N \\
\hline \multicolumn{2}{c}{ Kesembuhan Luka Perineum } & 15.00 & 0.000 & \multirow{2}{*}{0.042} & 5 \\
\hline Pre-Tes & 3.80 & 2.168 & & 5 \\
Post-Tes & & & &
\end{tabular}

Berdas arkan tabel 2 Efektifitas Frekuensi Responden pada Kelompok Kontrol Berdasarkan La ma Kesembuhan Luka Pada Ibu Nifas Di Klinik Sri Diana Lubis Mutiara Kecamatan Kisaran Tahun 2019. Dapat dilihat bahwa dari 5 ibu nifas di Klinik SriDianaLubis Mutiara Kisaran yang tid ak diberikan air rebus an daun binahong, 3 (60\%) orang ibu nifas yang mengalami sembuh secar a no rmal dan $2(40 \%)$ orang ibu nifas yang mengalami sembuh dengan lebih lama. Distribusi Rata-Rata Ke sembu han Luka Perineum Pada Ibu Nifas Kelompok Kontrol Menurut Penggukuran Per-Tes Dan Post-Test. Kesembuhan luka pada pengukuran Pre-Tes adalah 15.00 standar 0.000 sedangkan pengukuran Kesembuhan luka Post-Test adalah 1.80 standar 2.490, terlihat dari P-value 0.059 maka dapat disimpulkan ada perbedaan yang signifikan antara kesembuhan luka pre-test dan kesembuh an luka post-test pada kelompok kelompok kontrol. 
Tabel 2. Efektifitas Frekuensi Responden pada Kelompok Kontrol Berdasarkan Lama Kesembuhan Luka Pada Ibu Nifas Di Klinik Sri Diana Lubis Mutiara Kecamatan Kisaran Tahun 2019

\begin{tabular}{|c|c|c|c|c|}
\hline Kesembuhan & f & & $\%$ & \\
\hline Cepat & - & & - & \\
\hline Normal & 3 & & 60 & \\
\hline Lama & 2 & & 40 & \\
\hline Total & 5 & \multirow[b]{2}{*}{ SD } & 100 & \\
\hline $\begin{array}{c}\text { Variabel } \\
\text { Kesembuhan Luka Perineum }\end{array}$ & Mean & & P-value & $\mathbf{N}$ \\
\hline $\begin{array}{l}\text { Pre-Tes } \\
\text { Post-Tes }\end{array}$ & $\begin{array}{c}15.00 \\
1.80 \\
\end{array}$ & $\begin{array}{l}0.000 \\
2.490 \\
\end{array}$ & 0.059 & $\begin{array}{l}5 \\
5 \\
\end{array}$ \\
\hline
\end{tabular}

\section{PEMBAHASAN}

\section{Efektifitas Kesembuhan Luka Pre-Test dan Post-Test pada kelompok Eksperimen}

Dilihat dari uji Wilcoxon Signed Ranks Test berpasang yang digabungkan dalam kelompok Percobaan, itu menunjukkan bahwa $\mathrm{p}$-esteem adalah 0,042 , ini berarti $\mathrm{p}<0,05$,jadi ada perbedaan be sar dalam pemulihan cedera an tara pre-test dan post-test melilit memperbaiki dengan memberikan daun air menggelegak. palsu. Berdasarkan hasil tersebut, diduga terjadi peningkatan penyembuhan luka perine u m pada ibu pasca hamil yang diberi bubbled water dari daun binahong. Dalam pertemu an eksplorasi, $5 \mathrm{ibu}$ pasca kehamilan sembuh dari cedera perineum dengan cepat. Penelitian ini menunjuk kan bahwa daun binahong terpisah dapat mempercepat pengurangan ukuran luka perineum, hal ini menunjukkan terjadinya tindakan penyembuhan luka perineum pada wanita pasca hamil, kemampuan ini tidak dapat dibedakan dari adanya campuran dinamis, khususnya Saponin, Flavonoid, Alkaloid, dan Kolagen (Vit C). pada daun binahong yang dapat mempercepat penyembuhan luka perineum pada ibu pasca salin.

Tindakan penyembuhan luka tersebut saling berkaitan mulai dari mengecilnya ukuran luka diikuti dengan berkurangnya kemerahan pada luka perineum pada ibu pasca hamil, awal terjadinya luka perineum pada ibu nifas menunjukkan adanya rona kemerahan yang kental. bay angan $\mathrm{d}$ an $\mathrm{p}$ erubahan bayangan menjadi merah muda atau kabur dari 5 hari terakhir dalam jangka waktu pasca kehamilan. Lakukan perawatan luka dengan menggunakan air bergelembung daun binahong. Edema adalah jenis iritasi bengkok, dalam siklus ini terjadi perluasan aliran darah ke saluran ke jaringan y ang ru sak y ang berarti menarik protein plasma dan sel ke permukaan cedera untuk menghindari penyakit tambahan y an $g$ masuk.

Dari hasil pemeriksaan yang dipimpin oleh Riyanti Imron dan Risneni. Perbandingan Viab ilitas Povidone Iodinedan Rebusan Daun Binahong Terhadap Penyembuhan Cedera Perineum pada Ibu Pas ca Hamil di Ruang Kerja BPM Administrasi Kesejahteraan Rakyat Rezim Lampung Selatan Tahun 2017. Jenis pemeriks aan ini menggunakan rencana uji pasca eksplorasi Asli saja. Populasi dalam pemerik saan ini adalah seluruh ibu pasca hamil yang mengalami luka perineum yang melahirkan secara pervaginam di BPM di Ruang Kerja Administrasi Kesejahteraan Rakyat Lampung Selatan. Contoh yang diambil adalah 
e-ISSN 2774-4671

Vol.1 Nomor 2

Tahun 2021

Hal. $143-152$

\section{JURNAL ILMIAH KEBIDANAN}

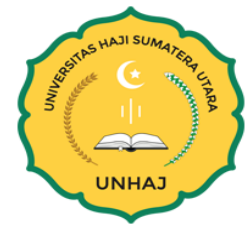

80 responden yang dipisahkan menjadi 2 pertemuan dengan berbagai mediasi. Khususnya $40 \mathrm{ibu}$ pas ca hamil diberikan pengobatan luka dengan Povidone Iodine dan 40 responden menggunakan rebus an Dau n Binahong. Informasi yang dikumpulkan adalah informasi penting dengan 3 persepsi. Informasi disiapkan dengan. menggunakan uji T gratis, persiapan informasi menggunakan PC. Akibat dari pe meriks aan ini didapatkan ibu pasca hamil yang diberikan pengobatan luka tusuk dengan Povidone Iodine, penyembuhan luka terlama adalah 7 hari, yaitu 38 responden (95\%) dengan masa penyembuhan normal 8 hari, sedangkan responden menggunakan rebusan jamu. Daun Binahong untuk penyembuhan luka. 5 hari dengan luka kering 20 responden (setengah). Waktu pemulihan normal adalah 5 hari. Berdasarkan hasil uji faktual dengan Uji T diperoleh bahwa uji beda uji T p esteem $=0,000 .<0,05$ sehingga H0 ditolak, hal ini menunjukkan bahwa terdapat perbedaan kritis antara perbaikan luka perineum dengan menggu nakan Povidone iodine dan gelembung air dari daun Binahong di Rumah Sakit Spesialis Bersalin Daerah Otonom Praktek Lampung Selatan tahun 2017.

Penelitian Roswita H F Nugu tentang Uji Potensi Ekstrak Daun Binahong (Anredera Cord ifo lia (Tenore.) Steenis) Terhadap Jumlah Fibroblas Dan Ketebalan Kolagen Pada Luka Bak ar Tik us Wistar Tahun 2018 menjelaskan bahwa penelitiannya yang menggunakan 24 ekor tikus wistar jantan yang dibagi menjadi 4 kelompok perlakuan yakni kelompok tanpa pengobatan, bioplacenton, ek strak etan ol daun binahong $20 \%$ dan ekstrak etanol daun binahong $40 \%$, kemudian tikus yang telah dibuat luka bakar diberi perlakuan kemudian diamati jumlah fibroblas dan ketebalan kolagen padahari ke-3 dan hari ke- 7 . Analisis data menggunakan One Way Anova dilanjutkan uji Duncan Test, mendapaatkan hasil bahwa ekstrak etanol daun binahong $40 \%$ dapat meningkatkan jumlah fibroblas paling signifikan, pada hari ke-3 $(245,33 \pm 32,87)$ dan hari ke-7 $(333,00 \pm 40,85)$ diikuti ekstrak etanol daun binahong $20 \%$ hari ke-3 $(164,00 \pm 7,00)$ dan hari ke-7 $(183,67 \pm 10,12)$. Ekstrak etanol daun binahong $40 \%$ meningkatkan ketebalan kolagen pada hari ke-3 $(22,82 \pm 1,72)$ dan hari ke-7 $(26,98 \pm 7,22)$ diikuti ekstrak etanol daun binahong $20 \%$ hari ke-3 (17.19 \pm 2.05$)$ dan hari ke-7 $(24,71 \pm 10,35)$. Dari hasil penelitian, dapat disimpulkan bahwa ekstrak etanol daun binahong $40 \%$ lebih efektif dalam mempercepat proses peny e mb uh an luk a bak ar dengan meningkatkan jumlah fibroblas dan ketebalan kolagen .

Hasil penelitian ini sesuai dengan penelitian terdahulu Pengaruh Mengkonsumsi Ek strak Dau n Binahong (Anredera Cordifolia (Tenore) Steen) Terhadap Lamanya Penyembuhan Luka Perineu m Pad a Ibu Post Partum Di Rsup Dr. Hasan Sadikin Bandung Periode Juli Tahun 2014. Penelitian ini bertu ju an untuk mengetahui pengaruh mengkons umsi ekstrak daun binahong terhadap lamanya penyembuhan lu ka perineum ibu post partum. Jenis penelitian adalah Quasi Eksperiment dengan post test only control group. Teknik pengambilan sampel pada penelitian ini adalah non probability sampling dengan jenis consecutive sampling dengan jumlah responden 40 orang. Hasil penelitian menu njukan lama penyembuhan luka jahitan perineum pada ibu post partum yang tidak mengkonsumsi ekstrak daun binahong hampir seluru h nya mengalami penyembuhan yang lambat yaitu $90 \%$ sedangkan yang mengkonsumsi ekstrak daun binahong hampir seluruhny a mengalami penyembuhan yang cepat yaitu $85 \%$ dengan $\mathrm{P}$ value $(0.000)<\alpha$ $(0,05)$. Kesimpulan penelitian adalah terdapat pengaruh yang signifikan mengk ons umsi ek strak d au n binahong terhadap lamanya penyembuhan luka perineum. Ekstrak daun binahong men jadi salah s atu alternatif untuk mempercepat penyembuhan luka perineum. 
e-ISSN 2774-4671

Vol.1 Nomor 2

Tahun 2021

Hal. $143-152$

\section{JURNAL ILMIAH KEBIDANAN}

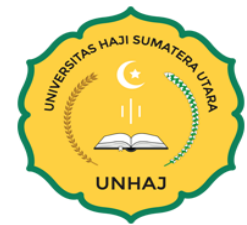

Penelitian lain juga mendukung hal tersebut yaitu dilakukan oleh (Oriza, 2015), yang menyatakan bahwa ekstrak daun binahong dapat memperecepat penyembuhan luka sayat pad a tikus putih dengan dosis efeltif yaitu konsentrasi $30 \%$, dibandingkan dengan povidone iodine. Penelitian lain dilakukan oleh (Firzanah, 2015), yang menyatakan bahwa ada pengaruh mengkonsumsi air rebusan daun binahong terhadap penyembuhan luka perineum pada ibu nifas. Hasil penelitian Nurul dan Anisa (2007), menyebutkan bahwa dalam simplisia daun binahong terkandung senyawa saponin, alkaloid, dan polifenol. Saponin berfungsi sebagai pembersih dan memacu pembentukan kolagen I, yang merupakan sebuah protein yang berpern dalam proses penyembuhan luka.

\section{Efektifitas Kesembuhan Luka dan Post-Test pada kelompok Kontrol}

Berdasarkan analisis uji Wilcoxon Signed Ranks Test berpasang pada kelompok Eksperimen menunjukkan, bahwa nilai pvalue adalah 0, 059 hal ini berarti $p<0,05$ maka terdapat perbedaan kesembuhan luka yang signifikan antara kesembuhan luka post-test dengan tidak diberikan air rebu san daun binahong. Berdasarkan hasil tersebut dapat disimpulkan bahwa terjadi penin gk atan kes em buh an luka perineum pada ibu nifas 2 hari postpartum yang diberikan air rebusan daun binahong pada kelompok eksperimen adalah 3 orang ibu nifas yang mengalami kesembuhan normal dan 2 or ang ibu nif as y ang mangalami penyembuhan luka lambat.

Kelompok eksperimen dan kelompok kontrol keduanya mengalami penin gk atan ke se m bu han luka setelah di intrvensi dengan pemberian air rebusan dan tidak di berikan air rebusan da un binah on $\mathrm{g}$. Akan pada kelompok yang diberikan air rebusan daun binahong mendapatkkan peluang yang bes ar untuk lebih cepat terjadinya kes embuhan luka perineum pada ibu nifas.

Menurut jurnal Sri Yuniarti dan Lies Mulyati den gan judul Pengaruh Mengko ns um si Ek strak Daun Binahong (Anredera Cordifolia (Tenore) Steen) Terhadap Lamanya Penyembuhan Luka Perin e um Pada Ibu Post Partum Di Rsup Dr. Hasan Sadikin Bandung Periode Juli Tahun 2014. Penelitian ini bertujuan untuk mengetahui pengaruh mengkonsumsi ekstrak daun binahong terhadap lamanya penyembuhan luka perineum ibu post partum. Jenis penelitian adalah Quasi Eksperiment dengan post test

only control group. Teknik pengambilan sampel pada penelitian ini adalah non probability sampling dengan jenis consecutive sampling dengan jumlah responden 40 orang. Hasil penelitian k menu nju kan lama penyembuhan luka jahitan perineum pada ibu post partum yang tidak mengkonsumsi ekstrak daun binahong hampir seluruh nya mengalami penyembuhan yang lambat yaitu $90 \%$ sedangkan yang mengkonsumsi ekstrak daun binahong hampir seluruhnya mengalami penyembuhan yang cepat yaitu $85 \%$ dengan $\mathrm{P}$ value $(0.000)<\alpha(0,05)$. Kesimpulan penelitian adalah terdapat pengaruh yang signifikan mengkonsumsi ekstrak daun binahong terhadap lamanya penyembuhan luka perineum. Ek strak daun binahong menjadi salah satu alternatif untuk mempercepat penyembuhan luka perineum.

Dari hasil penelitian yang dilakukan oleh Raden Roro Siti Hatati Surjantini dan Yusniar Sir egar Efektifitas Air Rebusan Simplisia Daun Binahong (Anredera Cordifolia (Tenore) Steen) Untuk Penyembuhan Luka Perineum Pada Ibu Nifas Di Klinik Murniati Kecamatan Kota Kisaran Barat Tah un 2018. Data dikumpulkan menggunakan lembar cek list dan dianalis a dengan Mann Whitney-U Test. Hasil penelitian menunjukkan bahwapada kelompok yang diberi simplisia daun binahong lama lu ka s e mbu h luka perineum mayoritas cepat sedangkan yang tidak diberikan simplisia daun binahong la ma sembuh 
e-ISSN 2774-4671

Vol.1 Nomor 2

Tahun 2021

Hal. $143-152$

\section{JURNAL ILMIAH KEBIDANAN}

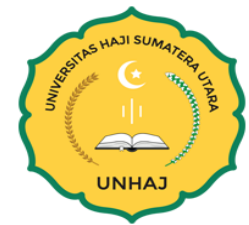

luka perineum normal. Hasil uji statistic dengan Mann-Whitney Test nilai $\mathrm{p}<0,05$ dis impulkan b ahw a simplisia daun binahong efektifitas mempercepat kesembuhan luka perineum. Kepada petugas kesehat an khususnya pelayanan kebidanan, perlu memberikan pendidikan kesehatan tentang cara peraw atan luka jahitan perineum saat dirumah dengan mengaplikasikan terapi komplementer termasuk dau n binahong untuk membantu mempercepat penyembuhan luka, karena pemberian air rebusan daun binahong membuat penyembuhan luka yang lebih baik.

Menurut skeripsi Ambar Rini Kuntoro dan Umi Laelatul Qomar yang berju dul Pen erap an Air Rebusan Daun Binahong Untuk Penyembuhan Luka Perineum Di Pmb Diana Yulita Sawangan Alian Kebumen Tahun 2018. Penelitian ini dilakukan dengan menggunakan metode deskriptif analitik, dengan pendekatan studi kasus (study case). Partisipannya adalah 5 partisipan ibu postpartum. Instrument penilaian yang digunakan untuk menilai penyembuhan luka yaitu skala reeda. Data diperoleh memalui wawancara, observasi, dokumentasi dan studi pustaka. Hasil: Setelah diberikan penera pan air rebu san daun binahong penyembuhan luka pada semua partisipan memiliki nilai 0 , partisipan pertama pada hari ke 7, partisipan kedua pada hari ke 6, partisipan ketiga pada hari ke 7, partisipan keempat pada hari ke 6 , dan partisipan kelima pada hari ke 8 .

Penyembuhan luka adalah suatu kualitas dari kehidupan jaringan, hal ini juga berhubunga dengan regenerasi jaringan. Penyembuhan luka dapat dipengaruhi oleh nutrisi yang adekuat, kebersihan, istirahat, posisi, umur, penanganan jaringan, hemoragi, hipovolemia, edema, defist oksigen, penumpukan drainase, medikasi, overaktivitas, gangguan sistemik, dan status imunosupresi. Faktor yang mempengaruhi penyembuhan luka perinium diantaranya : status gizi, merokok, penambahan usia, obesitas, diabetes melitus (DM), kortikos teroid, obat-obatan, gangguan oksigenasi, infeksi, dan stres luka.

Proses penyembuhan luka perineum pada ibu post partum dipengaruhi banyak faktor. Faktor faktor yang mempengaruhi penyembuhan luka dipengaruhi oleh faktor internal dan faktor ek sternal. Faktor-faktor eksternal yang mempengaruhi penyembuhan luka meliputi : lingkungan, tradisi, pengetahuan, sosial ekonomi, kondisi ibu, pemberian antibiotik, dan personal hygiene. Sedangkan faktor faktor internal yang mempengaruhi penyembuhan luka adalah usia, trauma jaringan atau infeksi, penanganan jaringan, hemoragi, hipovolemia, faktor lokal edema, defisit nutrisi, personal hy giene, defisit oksigen, jenis persalinan, jenis lukajahitan luka perineum, dan kadar hemoglobin.

Hasil observasi yang dilakukan oleh peneliti terdapat 5 orang ibu nifas yang men galami cepat sembuh pada luka perineum, dapat disimpulkan ada perbedaan yang signifikan antara kesembuh an luka pre-test dan kesembuhan luka post-test, pada kelompok eksperimen yang mengalami penyembu han luka cepat yang diberikan air rebusan daun binahong. Pada penelitian ini terlihat bahwa ekstrak daun binahong mampu mempercepat pengecilan ukuran luka perineum. Hal ini menunjukkan terjadinya proses penyembuhan luka perineum pada ibu nifas, kemampuan ini tidak terlepas dari adanya kandungan senyawa aktif yang terdapat pada daun binahong. Sesuai dengan teori, kandungan yang terdapat di dala $\mathrm{m}$ daun binahong yaitu pencairan senyawa sapoin akan memberikan hasil yang lebih baik sebagai anti bakteri, yang kandungnnya seperti Flavonoid, Asam Oleanolik, Protein, Asam Askorbar (vitamin C), bisa mengurangi ras a nyri dan mempercepat penyembuhan luka perineum pada ibu nifas. 


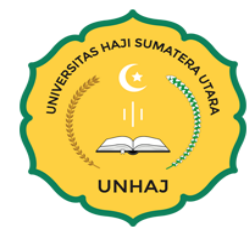

\section{KESIMPULAN DAN SARAN}

Kesimpulan penelitian ini bahwa ada pengaruh efektifitas air rebusan daun binahong dengan kesembuhan luka perineum padaibu nifas di Klinik Sri Diana Lubis Tahun 2019.

Dis arankan bagi petugas kesehatan agar mendukung ibu nifas untuk menggunakan air rebus an daun binahong bisa mempercepat kesembuhan luka perineum pada ibu nif as .

\section{UCAPAN TERIMA KASIH}

Terima kasih kepada Pimpinan Klinik Sri Diana Lubis Medan yang telah memberikan ijin un tuk melakukan penelitian

\section{DAFTAR PUSTAKA}

1. Fitriana Y, Nurwiandani W. Asuhan Persalinan Konsep Persalinan secara komp reh ensif dalam Asuhan Kebidanan. Yogyakarta: PT. Pustaka Baru; 2018. 208 p.

2. Fatimah Prasetya. Pijat Perineum. Yogyakarta; 2019.

3. Asih Y, Risneni H. Asuhan kebidanan nifas dan menyusui. JL. Man 6 No 74 Kramat Jati Jakaerta Timur: CV. Trans Info Media;

4. Susetya D. Khasiat dan Manfaat Daun Ajaib Binahong. Yogyakarta: Pustaka Baru; 2015.

5. Coverage HS, Protection F. 2017 Health SDG Profile: Indonesia 2017 Health SDG Profile: Indonesia. 2017;3:13-6.

6. Kepmenkes. Profil Kesehatan Tahun 2016 Indonesia. 2016.

7. Profil_Kesehatan_Indonesia. Profile Kesehatan Indonesia Tahun 2017. Ministry of Health Indonesia. 2018. 107-108 p.

8. Dinkes Medan. Profil Kesehatan Kota Medan Tahun 2016. Profil Kesehat sumatra utara.2016;

9. Pengantar K. Kota Binjai Tahun 2017.2017;

10. Maritalia dewi. Asuhan kebidanan pada ibu nifas. 1sted. Riyadi S, editor. Yogyakarta: Gosy en publish;2017.

11. Surjantini RRSH, Siregar Y. Efektifitas Air Rebusan Simplisia Daun Binahong (Anredera cordifolia (tenore) steen) Untuk Penyembuhan Luka Perineum Pada Ibu Nifas Di Klinik Murniati Kecamatan Kota Kisaran Barat. J Penelit Kesehatan" Suara Forikes"(Journal Heal Res Forikes Voice"). 2018;9(3):170-5.

12. Agus R, editor. Aplikasi Metodologi Penelitian Kesehatan. Yogyakarta; 2011.

13. Iman M. Panduan Penyusunan Karya Tulis Ilmiah Bidang Kesehatan Menggunakan Metode Ilmiah. Cetakan Ke. Razia Begum Suroyo, editor.Medan;2016. 80 p. 